\title{
Case Study of Science Teachers' Professional Development in Saudi Arabia: Challenges and Improvements
}

\author{
Amel Alshehry ${ }^{1}$ \\ ${ }^{1}$ School of Education, Najran University, Najran, Saudi Arabia \\ Correspondence: Amel Alshehry, School of Education, Najran University, Najran, Saudi Arabia. E-mail: \\ atalshehry@nu.edu.sa
}

Received: October 21, 2017

Accepted: November 23, 2017

Online Published: February 25, 2018

doi:10.5539/ies.v11n3p70

URL: https://doi.org/10.5539/ies.v11n3p70

\begin{abstract}
Professional development has a major role in addressing the skill gaps of teachers. Recently, much effort has been focused on improving teaching practices in Saudi Arabia. Here we aim to determine Saudi teachers professional development needs in the higher educational system. We also focus on skill needs, training programs, factors affecting teacher performance, and teacher's control of their own professional development. Here, through face-to-face interviews, we explore how current professional development strategies could be improved to better meet the needs of academic teachers views through face to face interviews data collection to address the questions of what teachers needs to develop and support their professional knowledge, how it affect their teaching methods and what opportunities and roles provided to them based on the instructional systems. Finally, the study illustrates how the professional development among based on their experiences and practice could be improved and how they encounter their participations and interaction to facilitate their development among higher educational institutions in Saudi Arabia.
\end{abstract}

Keywords: professional development, science teaching, training program, self-development, Saudi Arabia, teaching skills

\section{Introduction}

\subsection{The Importance of the Problem}

Teacher development is a major concern within the higher education system in Saudi Arabia. Here we focus on teachers' professional development and the challenges and successes associated with it. Most professional development strategies used for teaching practices shows a big challenge and critical issues in the way of improving teachers needs and tasks (Dillon, 2010). The principal objective of professional development is to change the teacher's approach from traditional methods to novel, professionally-developed methods of teaching. Most science education in Saudi Arabia is based on the principle that learning should be achieved by teaching the concepts of science to students, supported by the designing of experiments and observing, interpreting and discussing the results. In this case, it is important to focus on professional development, to teach students their instruction with the developed and updating ways for a problems and barriers solving through students teaching and learning (Wolf \& Fraser, 2008). Depending on the official direction on the curriculum planning, there is a great majority of teachers needs to practice their experience and knowledge on deciding their suggestion for any teaching concerns in the curriculum they taught through in the timetable of the courses revising some sections in the curriculum they taught (Alshehry, 2009).

According to Elmore (2002), professional development can be defined as an ongoing process that aims to enhance school environment teaching and learning, which is often bespoke for the subject and region. Teachers' activity mostly could be effective by their developed skills and knowledge development of teaching and learning issues. This might indicate a greater focus on successful teaching methods, such as teaching workshops.

Here, we focus on the importance of professional development provided for science teachers in girls' science colleges in Najran University sponsored by the Ministry of Education a part of university educational institutions. Our findings support the views expressed by teachers about the impact and importance of professional development (Terrell, 2003). To address science teachers' perceptions of their professional development needs, the following principal research questions were used to address teachers' current opinions about developing of 
teaching practices:

1) What types of professional development do you need to support your teaching knowledge and skills?

2) How do you think professional development would affect your teaching methods of science?

3) Within your institution, what opportunities and chances have teachers had to become actively engaged in teaching and learning science?

\section{Review of the Literature}

According to previous studies, such as Noh, Cha, Kang, and Scharmann (2004), efforts to improve professional development for teachers should focus on the teachers' needs and the practice and beliefs about instructions, curriculum, and assessments. Alshehry (2009) performed a case study of science colleges and concluded that there is a need for more opportunities for science teachers to plan their professional development.

To date, few studies have addressed the views of teachers on higher education in Saudi Arabia. However, during the mid-1970s, when the American University was established in Beirut, some studies were focused on improving science education in Saudi Arabia. According to Alghanem (1999), Saudi science teachers mostly concern the current and future needs that sort for all the students, some students, however, shows that science education in Saudi Arabia has been restructured to better deliver new curricula that include more science, mathematics, and social science projects (Obikan for research and development, 2010).

For developing countries, such as in East Asian, some authors have reported a need for greater acceptance of new ideas in order to give stability and local character to universities (Birman et al., 2000). The principal role of education in Saudi Arabia is to make decisions and set policies that support and implement the professional development of teachers. Almazroa et al. (2014) have proposed that most Saudi teachers do not meet the standards needed to deliver the new curricula.

However, most studies addressing this subject have focused on Western institutions, rather than Arab societies (Van Driel et al., 2001). Furthermore, this study might also investigate the type of need for professional development for academic staff to teach new curricula in different and important ways. For the continued professional development of teachers, it will be necessary to develop critical, analytical, evaluation and reflective corporations with a good knowledge and understanding of teaching practices (Ian Terrell, 2003). Most professional development inactivates involving science teachers have focused on laboratory sessions, experimental learning, and naturalization of theoretical information by application and observational methods (Harman et al., 2016). This will be explored by the second levels of master's programme among science colleges in the current positions which have not been explored by other international or national studies before.

Many institutions specializing in teaching methods emphasize the importance of improving teaching in the best way which could achieve high standards teaching quality of teaching and learning methods (Ashehry, 2009). Abd-El-Khalick (2005) has noted the importance of science teachers' understanding of the natural sciences and how this can be improved through professional development courses, ultimately leading to greater pupil involvement during teaching (Lederman, 1992). As in other international institutions, science teachers have important responsibilities, should be well-educational, and behave professionally, demonstrating sufficient skills and following best practices (Osman et al., 2006). Kaur and Wong (2017), in Singapore, reported how the Ministry of Education took measures to improve the professional bodies within teaching institutions. Therefore, the main purpose of this study is to determine how professional development were practicing and provided by exploring the perception of science teachers at one university institution in Saudi Arabia.

\section{Methodology}

In this study, qualitative interviewing was used to investigate the perceptions of science teachers towards professional development. Semi-structured interviews were used to elicit teachers' views and attitudes, allowing:

1) What types of professional development do you need to support your teaching knowledge and skills?

2) How do you think professional development would affect your teaching methods of science?

3) Within your institution, what opportunities and chances have teachers had to become actively engaged in teaching and learning science? us to probe and understand their thoughts on professional development.

\subsection{Research Questions}

The paper seeks to answer the following questions, with the sub-questions used during the data collection:

1) What professional development do you need to improve and support your teaching knowledge and skills? 
2) How do you think professional development would affect the methods you use to teach science?

3) Within your institution, what opportunities have teachers had to become actively engaged in the teaching and learning of science?

\subsection{Theoretical Framework and Research Model}

The first open-ended question focused on detecting the professional development that science teachers need to support their teaching before attending their real teaching of courses. The second open-ended question aimed to reveal how professional development might affect their teaching methods, especially of science. The third question addresses the opportunities that teachers have had to become actively engaged in teaching and learning. At this time, it was expected that science teachers views about professional development, purpose and challenged provided for teaching development depends on their perceptions and views about the importance of getting well background and experiences in science education. Further, the need of change, development and implementations after the investigation of this study.

\subsection{Sampling Procedures}

The study took place during the 2016-2017 academic year and included Level 8 science teachers within educational programs in Saudi Arabia. Thirty science teachers participated (all from biology departments). Three main questions were asked during the interviews, followed by six sub-questions depending on the flow of the responses. Using open-ended questions, the participants explored their ideas and views about professional development. In order to determine the research questions to be used in the instruments, thirty participants corporates as the status academic members (called teachers in the study) in science department working as science teachers were provided their views about the practices of professional development.

\section{Data Collection}

Data were collected during semi-structured interviews. We expect that our findings can be generalized because of the qualitative nature of the research and purposive sampling of the participants.

During the interview, the participant's responses were recorded in a notebook by the researchers. The interviews were semi-structured and consisted of open-ended questions. Six subsequent sub-questions were also developed (see Appendix). An initial pilot study was conducted with five participating science teachers. Based on our experience of this pilot study, as well as participant feedback, the data collection approach was modified and finalized. Finally, science teachers were asked to discuss their views on professional development relevant to science teaching.

\section{Data Analysis}

The participant responses were analyzed by contents analysis. To clearly illustrate the results, the data was organized by data coding approaches. Response frequencies and category percentages were also calculated. Furthermore, a response code of teacher responses was created according to the frequencies of the categories. As an inductive analysis, the codes were directly derived from the gathered data. In order to code themes, we first determined the similarities and differences of codes that emerged during the interview. The researcher, in this case, could build results through these themes whether is similar or different which it might be possible to interpret and identify the data according to certain facts. Following the collection of interview data, these data were inductively analyzed in order to understand the teachers' perceptions of professional development. The emergent categories for the research questions were coded into the main themes based on the teacher responses, including their attitudes. These responses reflect the teachers' experiences, needs, and attitudes towards professional development. After the coding of these interviews, the main emerged themes were revised and compared as a group of agreed responses according to the similarities and differences in the responses resulted in this study.

To determine the generalizability of this study, the teachers clearly drew upon their knowledge and experiences and understanding on the way they practice to construct their professional development. The answers provided by the teachers were similar to those reported in previous studies. The researcher's own verbal cues, together with the teachers' responses, provide confidence in the reliability of the responses (Fowler, 1993). However, the validity of the study is further supported by the multiple methods that were applied, including interviewing and observing the interviewees, as well as the comparison of the data from collected interviews.

\section{Results}

This study used descriptive data, such as measuring frequencies to analyze data. To achieve this, we calculated the mean values of the 30 participating teachers. Ranking of means was used to determining the principal professional development needs of the teachers. Before the test carrying out, the analysis was conducted in many steps 
including repeating the points of views of missing data with agreement or disagreement of the people responses. These findings raise questions about the importance of professional development among science teacher, as well as about the teachers' roles in self-development and long-term professional needs. These findings should be considered by the Saudi Ministry Of Education, as well as teaching institutions. During our analysis of the interview data, we identified three principal themes, each of which is addressed below.

The teachers expressed some differing opinions about their professional development needs. Some teachers focused on teaching, whereas others were more concerned about curriculum planning and the available facilities. These findings raise questions about the role of science teachers in developing their teaching style and experiences.

\subsection{What Professional Needs to Support Teaching?}

Among the participants, more than the half (22 out of 30) agree that there is a need for instruction aimed at supporting their teaching methods. Eleven participants stated that there is no need for additional instruction.

The teachers were asked about their perceptions of using instruments to enhance their teaching. In response, most mentioned that "the most important supporting activity is to practice my teaching in a professional setting". Other participants mentioned that "there is a relation between the presenting of the instrument and the training program we need that most of the subject ensures the best academic preparations of lectures with a new modern way of teaching". Others went further, stating that: "for example, we need to use instruments and technologies as a way of improving our teaching and to develop new teaching methods". Regarding the comparison of the needs perceived by the science teachers, one stated that "the lack of facilities demonstrates the association between professional teaching and skills/experiences". On another hand, some reported that "there's no effect on the use of facilities during teaching and no any effect on the methods of teaching".

Most of the participants (20 of 30) perceived the need for using of facilities in teaching science and how this agreed with the importance of professional development as using the labs, scientific inquiries for instructions based teaching and learning of science throughout field trips. This could be supported by, for example, as one said that "we need to be awarding when we qualified out teaching methods to shows a positive environment for both students and their teaching staff".

In response to the question "How could training programs help to improve teaching?", 16 of the 30 participants agreed that training programs could be useful. One staff member elaborated on this point, stating that "to improve, we need more focus on developing professional methods of teaching". Another perception also said that "training programs are a positive way of improving teaching methods".

\subsection{Practicing and Professional Development}

The more breaking out of the research questions we got in this case, the more result raised such as that the more need higher institutions for professional development among teaching processes. Fourteen of the participants agreed that the department has the greater proportion of responsibility for providing training programs for teachers. Most of the participants mentioned that "the institutions are responsible for training us to up gave and improve our status of levels to be highly elegance".

However, regarding the importance of self-development and training programs, 14 teachers reported that they had developed their teaching style through self-development. Some teachers mentioned that "we could develop our teaching weakness by ourselves; this is a new and increasingly used technique for improving our teaching". Another participant said that "there are multiple choices available for us through information technology to develop our teaching methods". Some teachers reported that, through self-development, they were now able to teach their students by distance learning: "using distance learning, I can better balance my at-home and teaching responsibilities". Another agreed that "by teaching development with e-learning and distance instructions, my students can now contact me at any time of the day". Fourteen of the participants agreed on the importance of self-development for professional teaching, while 16 thought that self-development could be used to improve instructions during class.

One teacher elaborated on this point, stating that "the department is responsible for deciding what we need to develop our teaching". A principal concern was that "we don't focus on the problem of professional development; the main point here is that we need sufficient instructions and teaching support instruments to develop our teaching style and to allow us to participate in self-development".

\subsection{Decision-Making Regarding Professional Development}

Twenty of the 30 participants agreed on the need for the strong relations of providing their suggestions and decisions about some agreement of for example the training of some specific program on the improvement of 
teaching methods of science among their environmental work. One interviewee stated that "there is a strong need of making our decisions into consideration for any relation pedagogical skills, knowledge and professional development". Other participants also pointed out that "if we are participating as teachers in some of the decisions made by the head or the administrative offices, there would be many changes in teaching development". Other teachers elaborated on this point, stating that "we will be as one team that faces those challenge affecting us as teachers and our students as learners". Furthermore, other interviewees said that "student feedback will help us to improve and deliver better teaching in the future".

Whereas ten of the participating teachers show no any sign pf participation in providing their decision or suggestion in teaching concepts or improvement issues as a professional development of teaching. The means of responses was explored the situations of concerning the decision made by teachers regarding their science teaching issues and problem solving. In line with this finding, ten of the participants agreed that "even if we present our opinions, this is unlikely to improve our professional development", and "I think self-development would be a more effective way of improving any concerns or weakness in our teaching approach".

However, most of the participants disagreed with the above teachers' responses. In addition, professional development could be taken into account during the placed of curriculum planning which can be approved by the department consultation by a group of professional teachers with a well background of teaching an learning. One participant insisted that "the curricula arrive ready-for-use and to be followed". Another participant stated: "this is useless unless the department acted on our concerns and addressed the problems we face during teaching". One more participant stated "we need to participate and get a chance to suggest and give our opinion on improving the curriculum we taught and get this approved by the department we belong to". The other interviewees agreed with this that "this is useless unless the department acted on our concerns and addressed the problems we face during teaching".

\section{Discussion}

Our findings are consistent with those of Wolf and Fraser (2008), expressed that these differences belong to their attitudes among the professional development that has contributed the gaps between their teaching practices and actual professional development. These authors also found that the teachers were mostly aware of their professional development needs. Based on our findings, we believe that it is important that science teachers' voices are heard and taken into consideration when developing training to help deliver new teaching approaches to students. We propose that there is a need for greater cooperation between decision-makers/policyholders and science teachers regarding professional development, which has also been noted in previous studies (Van Driel et al., 2001, Alshehry, 2009).

The implication of this study could be raised the effects of considering the professional development among teaching of science and needs to be given to the areas where improvement are the greatest. The treat of professional development among teachers needs must be focused and prioress as a required issues for their teaching evaluation rather than something choices. Therefore, planning professional development for teachers are in a challenge in the way of for example improve teachers experience, beliefs and positive expectations about the importance of professional development in the teaching environment. Most of the teachers with their existing experiences bring their practices, perceptions and feelings to the nature of their teaching work effectively (Chval et al., 2008).

Also, we identified directions for further research related to the perceived needs of science teachers' professional development. In future work, it will be important to remind the participants of the need for professional development and to perform follow-up interviews to establish the impact of professional development programs.

Qualitative research findings have been contradicted by student feedback about their teacher's professional development and how it has affected their teaching. Furthermore, future research should explore the role, actions, and views of other policymakers involved in curriculum development and science education strategies. In this study, the participating Saudi science teachers expressed a rather homogenous view of professional development. These findings suggest that most Saudi science teachers have similar professional development needs, with only minor effects from teaching experience, skills, and background (Almazroa et al., 2014).

The majority of teachers expressed a need for supporting facilities, assistance presenting of laboratory sessions, professional training programs. These findings are largely in line with previous studies addressing professional development among science teachers (Noh, Cha, Kang, \& Scharmann, 2004; Alshehry, 2009; Harman et al., 2016). We found that the participating teachers lack some basic knowledge and experience (e.g., self-development to improve their teaching style, the lack of using some new facilities and updates the methods of teaching, not being able to proving their opinions suggested in their decision made). 
This could indicate that there's a need for a good relationship between teachers preparation and standards-based refer to improve the mean of professional development which all will supply to their professional development teaching science in the best way. According to affect ways to improve professional development (Birman et al., 2000); this could be practiced by for example network activities as learning as it has on the active learning and coherence. Previous studies have reported on professional development opportunities aimed at individual (one-on-one) and group teaching strategies. The importance of teacher cooperation for has also been discussed. Also, teachers should be sufficiently informed about scientific innovations, belief, supporting their self-development and motivating themselves to teach improvement.

Thus, we propose that professional development aimed at improving the teaching of laboratory sessions should focus on encouraging the students by fostering positivity (Teixeira-Dias et al., 2005). Also, hands-on activities help students to develop scientific knowledge, as well as multiple other skills (Witteck et al., 2007).

\section{Conclusion}

While science teachers share a number of professional development needs among the teaching process, they also have some factors that lack their improvement and focusing on professional development to meet students need such as the providing of resources and facilities, offered training program and the presenting of suggestions and ideas to be allowed in decision making to those how direct science education among the educational department. This study explored the need for every science teacher as professional development to participating and assessed before planning and instituting the activities (Obikan, 2010).

In this study, the participant responses were largely homogenous and emphasized the need for professional development opportunities. This must be approved in Saudi Arabian decision making among universities institutions as other relative Asian studies (Kaur \& Wong, 2017) encouraged the implementing a specialized professional teaching committees that collaborated any concerting issued regarding the teaching if science and teachers professional development. In addition, these strategies benefit the teachers by encouraging them to foster positivity and develop a collaborative environment that involves their colleges, thereby improving their teaching style and professional fulfillment.

In conclusion, based on our findings, the Saudi educational system should provide further professional development opportunities for science teachers and involve teachers in decision-making regarding teaching practices, training programs, and available resources. This would likely lead to improved teaching standards for science in Saudi Arabia.

\section{Recommendation for Further Study}

We propose that further research should include additional research on teachers areas of concern of professional training on just one focused method for example quantitative approach to enrich the collections of data. Similar studies should also be made in other Arab countries, especially Gulf countries. This would establish whether science teacher in these countries shares the view of Saudi science teachers. Also, data collection should be expanded to include multiple interviews and geographic areas. Even though there is limitation associated with this process, the study has confidence representations that reveal the teachers' attitudes towards their professional development among teaching.

\section{Acknowledgments}

I wish to express my heartfelt gratitude to the staff of The Education Department of Curriculum and Teaching Methods for their participation and support of this project and for providing relevant guidance. My sincerest thanks to the reviewers for their invaluable comments and scrutiny, which assisted this study tremendously.

\section{References}

Abd-El-Khalick, F. (2005). Developing deeper understandings of nature of science: the impact of a philosophy of science course on preservice science teachers' views and instructional planning. International Journal of Science Education, 27, 15-42. https://doi.org/10.1080/09500690410001673810

Alghanem, G. (1999). Reforming science education in Saudi Arabia: A conceptual framework for the design of coordinated and thematic science (CATS) module for grades 7-9 (Unpublished Ph.D. dissertation). West Virginia University, Morgantown: West Virginia. Retrieved from https://search.proquest.com/docview/304535165

Almazroa, H., \& Al-Shamrani, S. (2015). Saudi science teachers' professional development. Science Education in the Arab Gulf States, 3-21. https://doi.org/10.1007/978-94-6300-049-9_1

Alshehry, A. (2009). Perceptions of science education for girls in Saudi Arabia higher education: a case study of 
female biology teachers (Unpublished Ph.D. thesis). University of Nottingham, Nottingham, United Kingdom.

Birman, B. F., Desimone, L., Porter, A. C., \& Garet, M. S. (2000). Designing professional development that works. Educational Leadership, 28-33. $\quad$ Retrieved from http://www.vodppl.upm.edu.my/uploads/docs/edu5822_1456883720.pdf

Chval, K., Abell, S., Pareje, E., Musikul, K., \& Ritzka, G. (2008). Science and mathematics teachers' experiences, needs, and expectation regarding professional development. Eurasia Journal of Mathematics, Science \& Technology Education, 4(1), 31-43. https://doi.org/10.12973/ejmste/75304

Dillon, J. (2010, February). Towards the professional development of science teachers. Paper Presented at the International Seminar, Professional Reflections, National Science Learning Centre, York.

Elmore, R. F. (2002). The testing trap. Harvard Magazine, 105(1), 35-37.

Fowler, F. J. (1993). Survey research methods (2nd ed.). Newbury Park, CA: Sage Publications.

Harman, G., Cokelez, A., Dal, B., \& Alper, U. (2016). Pre-service science teachers' views on laboratory applications in science education: the effect of a two-semester course. Universal Journal of Educational Research, 4(1), 12-25. https://doi.org/10.13189/ujer.2016.040103

Kaur, B., \& Wong, L. (2017). Professional development of mathematics teachers in Singapore. Professional Development of Mathematics Teachers, 97-108. https://doi.org/10.1007/978-981-10-2598-3_8

Martinez, R., \& Fernandez, P. (2010). The social and economic impact of illiteracy: Analytical model and pilot study. Anesthesiology, 104(4), 872-880

Noh, T. Cha, J., Kang, S., \& Scharmann, C. (2004). Perceived professional needs of Korean science teachers majoring in chemical education and their preferences for online and on-site training. International Journal of Science Education, 26(10), 1269-1289. https://doi.org/10.1080/0950069042000205422

Obikan for Research and Development. (2010). Projects of mathematics and naturals sciences. Retrieved January 28, 2012, from http://msd-ord.com/project.htm

Osman, K., Halim, L., \& Meerah, S. (2006). What Malaysian science teachers need to improve their science instruction: a comparison across gender, school location and area of specialization. Eurasia Journal of Mathematics, Science and Technology Education, 2(2), 58-81. https://doi.org/10.12973/ejmste/75453

Terrell, I., Powell, E., Furey, S., \& Scott-Evans, A. (2003). Teachers' perceptions of the impact of CPD: An institutional case study. Journal of In-service Education, 29(3), 389-404. https://doi.org/10.1080/13674580300200282

Van Driel, J. H., Beijaard, D., \& Verloop, N. (2001). Professional development and reform in Science Education: the role of teachers' practical knowledge. Journal of Research in Science Teaching, 38(2), 137-158. https://doi.org/10.1002/1098-2736(200102)38:2<137::AID-TEA1001>3.0.CO;2-U

Wolf, S. J., \& Fraser, B. J. (2008). Learning environment, attitudes and achievement among middle-school science students using inquiry-based laboratory activities. Research in Science Education, 38(3), 321-341. https://doi.org/10.1007/s11165-007-9052-y

\section{Appendix}

1) What type of professional development do you need to improve and support your teaching knowledge and skills? How do you know that you currently get sufficient professional development opportunities?

2) How do you think professional development would affect the methods you use to teach science? How do you describe your role as a teacher in your professional development?

3) Within your institution, what opportunities have teachers had to become actively engaged in the teaching and learning of science? How does your department take your participation and decision making into consideration?

\section{Copyrights}

Copyright for this article is retained by the author(s), with first publication rights granted to the journal.

This is an open-access article distributed under the terms and conditions of the Creative Commons Attribution license (http://creativecommons.org/licenses/by/4.0/). 